\title{
The impacts of different habitats on the development of Telekia speiosa (Schreb.) Baumg.
}

\author{
Csabai, J. ${ }^{1,3}$, Nagy, Z. 2,1 \& Tilly-Mándy, A. ${ }^{3}$ \\ ${ }^{1}$ Nyíregyháza Botanical Garden, 31/b Sóstói út, Nyíregyháza, $H-4400$ \\ ${ }^{2}$ University of Debrecen, 1 Egyetem tér, Debrecen, $\mathrm{H}-4010$ \\ ${ }^{3}$ Corvinus University of Budapest, Faculty of Horticultural Sciences, 29-43 Villányi út, Budapest, H-1118
}

\begin{abstract}
Summary: Telekia speiosa (Schreb.) Baumg. is a 100-150 cm high bushy perennial, which has yellow flowers and smells good. According to the descriptions (Farkas, 1999), it can be detected in two smaller areas within Hungary, namely in the Bükk hills and on the Szatmár-Bereg Plain. By the time of writing this paper, the population around Tiszabecs has already got extinct. Therefore, it is a protected relict species. It is named in honour of Sámuel Teleki, chancellor of Transylvania. Within the frame of the experiment, the Telekia speciosa (Schreb.) Baumg. was planted to places differently illuminated (sunny, semi shadow, shade), then the morphological changes brought about the various light conditions were investigated. The experiment was launched with a stock sown in October 2008. The seedlings were planted to three beds with diverse light conditions. The area of each bed was $1 \mathrm{~m}^{2}$, and ten seedlings were planted per $\mathrm{m}^{2}$. The parameters investigated are as follows: the length of leaf blade, the width of leaf blade, the length of petiole, the number of leaves per plant, and the alterations of leaves. As a result of our research, we can state that semi shadow is the optimal habitat for the plant. Under such ecological conditions the highest leaf production was observed, the leaves were species specific, healthy and big. The mean number of leaves per plant was 6.6 , the mean length of blade was $16.6 \mathrm{~cm}$, the mean width of blade was $13 \mathrm{~cm}$, while the mean length of petiole was $14.2 \mathrm{~cm}$. In the shade the plants grew poorly and the size of leaves were smaller. The mean number of leaves per plant was 4.1, the mean length of blade was $8.6 \mathrm{~cm}$, the mean width of blade was 7.1 $\mathrm{cm}$, and the mean length of petiole was $9.4 \mathrm{~cm}$. In the sunny habitat a similarly high leaf production was observed as in the semi shadow; however, the leaves had brownish spots, they shriveled, feel rough, so they revealed a reduced aesthetical value. The mean number of leaves per plant was 6.6 , the mean length of blade was $17.8 \mathrm{~cm}$, the mean width of blade was $11.3 \mathrm{~cm}$, and the mean length of petiole was $13.1 \mathrm{~cm}$.
\end{abstract}

Key words: Telekia speciosa (SCHREB.) BAUMG, protected plant, light condition

\section{Introduction}

Telekia speiosa (Schreb.) Baumg. is a 100-150 cm high bushy perennial. Clump forming plant with large hairy heart shaped aromatic 30-35 cm long leaves remaniscent of cane sugar. Attracts butterflys and beneficial insects with its bright yellow fuzzy flowers. The diameter of the flower is $6-8 \mathrm{~cm}$. Ray florets are narrow and dark yellow. Flowering period: June - August. The fruit of the plant is cypsela. An easy care standout that does well in moist areas and shade. According to the descriptions (Farkas, 1999), it can be detected in two smaller areas within Hungary, namely in the Bükk hills and on the Szatmár-Bereg Plain. By the time of writing this paper, the population around Tiszabecs has already got extinct. Therefore, it is a protected relict species. It is named in honour of Sámuel Teleki, chancellor of Transylvania.

According to the results of the investigations of Dobolyi the most frequent occurrence of Telekia speciosa is in mountainous regions, in beeches, in alder woodlands, in suffruticose associations of creeksides, and on roadsides. Ecological requirements of Telekia speciosa: slightly acidic, neutral of slightly basic, humid soil with good nutriment and water supply; cool, steady climate (Dobolyi, 1983).
Telekia speciosa (Schreb.) Baumg. is a relatively recent synanthropic neophyte in Central Europe originating from a Southeast European-Caucasian natural distribution area, introduced to Germany in the course of the establishment of landscape gardens in the second half of the 19th century. To date, it has not been known to host powdery mildew in Germany (Boyle et al., 2007). Nowdays this plant has two typical causative agents, the Golovinomyces cichoracearum (DC.) V. P. and the Coleosporium telekiae Thüm. (Kabaktepe et al., 2005).

Bernáth investigated thye plant of Solanum dulcamare, planted differently illuminated habitat. The plant had a strong reaction on the several light conditions. With the growth of the light condition decreased the height of the climber, the LAI, and the length of the internodes (Verbal informations of Bernáth, 2009).

\section{Materials and methods}

Following the research of Bernáth, we planted Telekia speciosa plants (Schreb.) Baumg. to differently illuminated places (sunny, semi shadow, shade), then the morphological changes brought about the various light conditions were investigated 


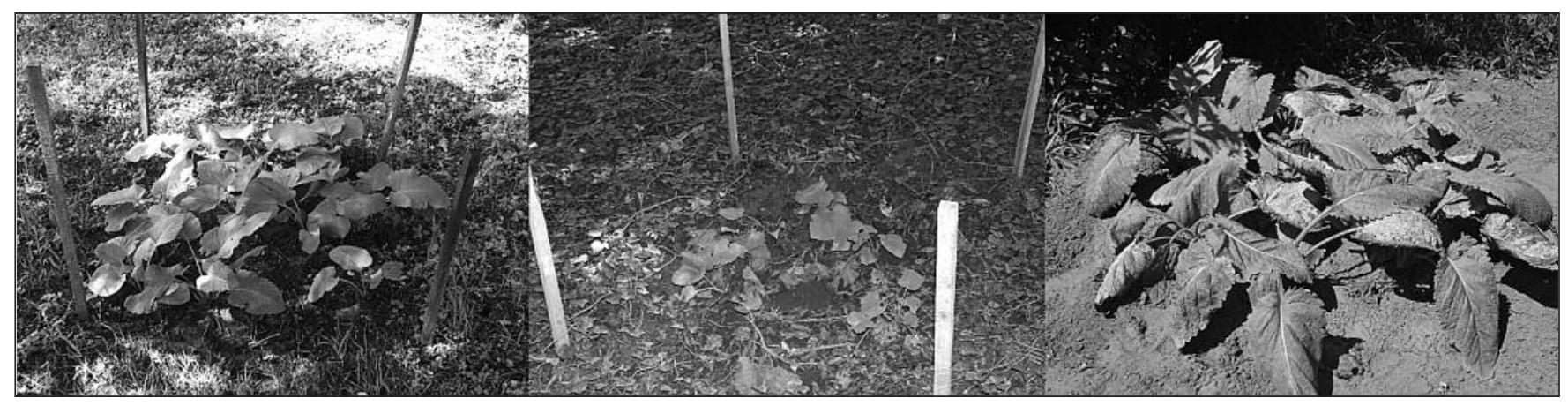

Figure 1. Telekia speciosa (Schreb.)Baumg at semi shadow (left), at shadow (middle) and at sunny (right) habitat.
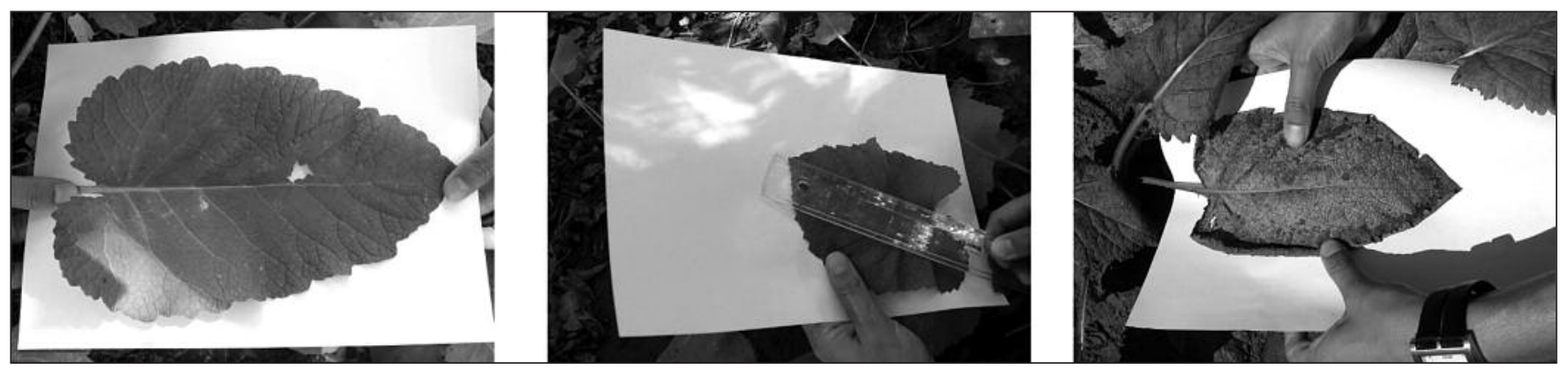

Figure 2. Leaf size of the Telekia speciosa (Schreb.)Baumg at semi shadow (left), at shadow (middle) and at sunny (right) habitat.

(Fig. 1.). The tree living areas were appointed in the Botanical Garden of Nyíregyháza. The area of each bed was $1 \mathrm{~m}^{2}$, and ten seedlings were planted per $\mathrm{m}^{2}$. The experiment was launched with a stock sown in October 2008. We planted the seedlings in 30. april 2009 to several beds with diverse light conditions.

The statistical analysis involved analysis of variance followed by Tukey's test, using the SPSS 7.5 for Window program.

\section{Results and discussion}

We measured the plants on 10. 08. 2009. The parameters investigated are as follows:

1. the length of leaf blade

2. the length of petiole

3. the width of leaf blade

4. the number of leaves per plant,

5. and the alterations of leaves

Table 1. contains the results of measures.

The different small letters in each row indicate significant differences $(\mathrm{P}<0,05)$ between the different habitat.

We can notice, that significant discrepancy was in the investigated parameters at different habitat.

In the case of the length of blade, the shadow living area gave separate subset, the data of semi shadow and sunny

Table 1. The variation of blade length of Telekia speciosa (Schreb.) Baumg. at different habitat.

\begin{tabular}{|l|c|c|c|c|}
\hline $\begin{array}{l}\text { The parameters } \\
\text { Type of the habitat }\end{array}$ & $\begin{array}{c}\text { Mean number of } \\
\text { leaves per plant }\end{array}$ & $\begin{array}{c}\text { Mean length } \\
\text { of blade (cm) }\end{array}$ & $\begin{array}{c}\text { Mean width } \\
\text { of blade (cm) }\end{array}$ & $\begin{array}{c}\text { Mean length } \\
\text { of petiole (cm) }\end{array}$ \\
\hline shadow & 4, 1-a & $8,6-\mathrm{a}$ & $7,2-\mathrm{a}$ & $9,4-\mathrm{a}$ \\
\hline semi shadow & $6,6-\mathrm{b}$ & $17-\mathrm{b}$ & $13,1-\mathrm{c}$ & $14,2-\mathrm{b}$ \\
\hline sunny & $6,6-\mathrm{b}$ & $17,8-\mathrm{b}$ & $11,3-\mathrm{b}$ & $13,1-\mathrm{b}$ \\
\hline
\end{tabular}

Boyle, H., Dietrich, S. \& Brautigam, W. (2007): First report of the powdery mildew Golovinomyces cichoracearum on Telekia speciosa in Germany, Czech Mycol. 59. (2): 201-204.

Dobolyi, Z.K. (1983): The cenological relations of Telekia speciosa (Schreb.) Baumg. in the Carpathian Mts. and the Balkan Peninsula (Compositae). Ann Hist Nat Mus Natl Hung. 75: 71-96.

Farkas, S. (1999): Magyarország védett növényei. Mezőgazda Kiadó. Budapest. 13-60.

Kabaktepe, S., Zeliha Bahcecioglu 2005. Seven rust species recorded as new to Turkey. Mycotaxon 91: 393-396. 